\title{
Informacje/Information
}

DOI : $10.14746 /$ pp.2020.25.1.13

\section{Między byciem sobą i możliwością stania się kimś innym - rozmowa z Zygmuntem Baumanem}

Ostatnie lata przynoszą nowe publikacje odnoszące się do biografii oraz osobowości Zygmunta Baumana. Co więcej, jego imponujący dorobek naukowy stale poddawany jest rozlicznym reinterpretacjom i ocenom. Twórca koncepcji płynnej nowoczesności przywoływany jest przez reprezentantów rozmaitych dziedzin nauki, co stanowi swoiste potwierdzenie samoświadomości samego Baumana, który mawiał: Jestem eklektykiem i jestem z tego dumny. Biorę od różnych ludzi elementy i sktadam je w catość ${ }^{1}$.

Wśród polskich publikacji okołobaumanowskich ostatnich lat można wymienić chociażby następujące pozycje: D. Brzeziński, Zygmunta Baumana krytyka kultury konsumpcyjnej. W realiach Polski Ludowej i współcześnie, w: Przemiany kulturowe we współczesnej Polsce. Ramy, wtaściwości, epizody, red. J. Kurczewska, Warszawa 2016; D. Brzeziński, List w butelce. O ocalonym dziele Zygmunta Baumana, w: Zygmunt Bauman. Szkice z teorii kultury. Warszawa 2017; D. Brzeziński, Redukcja i proliferacja wieloznaczności: Teoria kultury Zygmunta Baumana w polskim okresie jego twórczości, „Studia Socjologiczne”, nr 224, 1/2017; M. Burzyk, M. Jędrzejek, Wszystkie życia Zygmunta Baumana, „Znak”, nr 752, 1/2018; Z. Bauman, Bauman: czynić swojskie obcym: rozmowy Petera Haffenera z Zygmuntem Baumanem, Warszawa 2019 czy D. Rosiak, Bauman, Kraków 2019.

Publikowana przez „Przegląd Politologiczny” rozmowa wpisuje się w przestrzeń współczesnego zainteresowania spuścizną Baumanowską. Materiał stanowi główną część wywiadu, którego Zygmunt Bauman udzielił 21 lutego 2012 roku w swoim domu w Leeds. Warto zatem zauważyć, że data rozmowy zbiega się z okresem, w którym uczony przygotowywał wznowienie głośnej Plynnej nowoczesności, po raz pierwszy wydanej w roku 2000.

W toku kilkunastu lat pomiędzy upublicznieniem pierwszego i drugiego wydania przywołanej książki, Bauman wielokrotnie zastanawiał się nad adekwatnością zaproponowanej przez niego metafory. Wydaje się słusznym pogląd, że z czasem jego wątpliwości w tej kwestii narastały. Sytuacja ta skłaniała do poszukiwań nowego sposobu charakteryzowania czasów współczesnych.

O procesie tym Bauman pisze wprost w pierwszych akapitach wstępu poprzedzającego wznowioną wersję przywołanej pracy. Przypomnijmy, iż wstęp do tejże, noszący tytuł „Liquid Modernity Revisited", rozpoczyna się następującymi słowy:

Kiedy ponad dziesięć lat temu próbowatem rozpakować znaczenie metafory 'płynności' $w$ jej zastosowaniu do obecnie praktykowanej formy życia, jedna z tajemnic natrętnie nawiedzajaca mnie i opierająca się rozstrzygnięciu byt status płynno-nowoczesnej kondycji ludzkiej: czy było to napomknienie, wczesna wersja, zapowiedź czy zwiastun rzeczy, które miały nadejść? Czy też było to raczej chwilowe i przejściowe - a także nieskończone, niekompletne i niespójne - tymczasowe rozstrzygnięcie; odstęp między dwoma odrębnymi, ale żywotnymi i trwatymi, kompletnymi i spójnymi odpowiedziami na wyzwania ludzkiej wspólnotowości?

I do tej pory nie zblizyłem się do rozwiązania tego dylematu, ale jestem coraz bardziej skłonny, by przypuszczać, że obecnie znajdujemy się w czasie 'interregnum', - gdy stare sposoby robienia czegoś już nie działaja, dawniej wyuczone albo odziedziczone sposoby życia nie przystaja

${ }^{1}$ Z. Baumana w rozmowie z W. Goldkornem w: D. Rosiak, Bauman, Kraków 2019, s. 213. 
już do obecnej conditio humana, lecz nowe drogi radzenia sobie z wyzwaniami $i$ nowe sposoby życia lepiej dostosowane do nowych warunków nie zostały jeszcze wynalezione, umiejscowione $i$ wdrożone do działania... Nie wiemy jeszcze, które z istniejacych form i ustaleń będa musiały zostać 'uptynnione' ['liquidized'] i zastapione, choć żadne nie wydają się być odporne na krytyke, a wszystkie lub prawie wszystkie z nich $w$ tym lub innym momencie przeznaczono do wymiany [tłum. H.M. $]^{2}$.

Wydaje się, że chęć rewizji dotychczasowych poglądów, jak również poszukiwania nowej formuły opisu współczesności, wybrzmiewają także w wypowiedziach Baumana prezentowanych Czytelnikowi „Przeglądu Politologicznego”. Profesor w toku publikowanej rozmowy nie stroni od formułowania hipotez oraz wniosków „na próbę”. Nie waha się także swobodnie modyfikować swoich wypowiedzi, w pewnym sensie testuje je, wypowiadając na głos w obecności młodego słuchacza zainteresowanego problematyką tożsamości jako kategorii w przestrzeni nauk społecznych.

Z powyższych względów publikowany materiał można odebrać jako zapis rozmowy dość lekkiej, w ramach której Bauman wypowiada się niezobowiązująco. Wydaje się jednak, że tego typu konwersacje podejmował często - traktując je jako okazję do cyzelowania formy i treści głoszonych przezeń poglądów. Tym samym, rozmowa być może przybliża nieco Baumanowski warsztat pracy. To właśnie, w moim przekonaniu, sprawia, iż warto ją opublikować jako materiał o charakterze informacyjno-dokumentacyjnym.

Niestety, materiału nie udało się autoryzować przed śmiercią Zygmunta Baumana. Wersję prezentowaną czytelnikowi „Przeglądu Politologicznego” skonsultowano jednak z najbliższą rodziną uczonego. Niezbędne zmiany redakcyjne starano się ograniczyć do minimum. Oryginalny i pełen zapis rozmowy został zdeponowany w archiwum Baumanowskim w Leeds.

\section{Ryszard Hubert MILAS}

Ryszard Hubert Milas: Heinz Lichtenstein wyrażając swoje poglądy zbieżne z poglądami Erika Hamburgera Eriksena stwierdza: Każda definiowalna tożsamość wymaga od nas byśmy traktowali siebie, jako przedmioty, co oznacza zrównywanie tożsamości z tożsamościa nadawana nam przez role społeczne. Zatraca się przez to poczucie tożsamości, jako czystej aktualności istnienia. Stąd moje pytanie: Czy swoją tożsamość zawsze należy interpretować i zgłębiać poprzez pryzmat pełnionych ról społecznych?

${ }^{2} \mathrm{~W}$ oryginale: "When more than ten years ago I tried to unpack the meaning of the metaphor of 'liquidity' in its application to the form of life currently practised, one of the mysteries obtrusively haunting me and staunchly resisting resolution was the status of the liquid-modern human condition: was it an intimation, an early version, an augury or a portent of things to come? Or was it, rather, a temporary and transient - as well as an unfinished, incomplete and inconsistent - interim settlement; an interval between two distinct, yet viable and durable, complete and consistent answers to the challenges of human togetherness?

I have not thus far come anywhere near to a resolution of that quandary, but I am increasingly inclined to surmise that we presently find ourselves in a time of 'interregnum' - when the old ways of doing things no longer work, the old learned or inherited modes of life are no longer suitable for the current conditio humana, but when the new ways of tackling the challenges and new modes of life better suited to the new conditions have not as yet been invented, put in place and set in operation ... We don't yet know which of the extant forms and settings will need to be 'liquidized' and replaced, though none seems to be immune to criticism and all or almost all of them have at one time or another been earmarked for replacement". Z. Bauman, Liquid Modernity, CambridgeMalden 2012. 
Zygmunt Bauman: O nie, więc Max Frisch, też Niemiec piszący po niemiecku, ale Szwajcar $\mathrm{z}$ urodzenia, w swoich dziennikach bardzo mądrze zdefiniował, co to znaczy mieć tożsamość? To znaczy opierać się definicji, jaką ci narzucają.

R.H.M.: Opierać się definicji, jaką ci narzucają?

Z.B.: Tak, jaką ci narzucają. Nie przyjmować tej definicji, tych definicji, które inni tobie dają. Móc się przeciwstawiać. Mieć tę sprężynowość, jakąś odporność. Naciskają, ale ja się nadmę i to odpadnie w jakiś sposób. I obawiam się, że obaj wybitni wielcy pisarze, których przed chwilą cytowaliśmy, jednego Pan, drugiego ja, że obaj mają rację. No, ale to jest ciemny już ocean ambiwalencji, do którego wracam, bo dla mnie to jest centralny problem. Właśnie ta dwojakość intencji. Dwojakość impulsu. Dwojakość konieczności, jakie składają się na problem tożsamości. Problem tożsamości - gdyby nie było tej dwoistości, to by nie było problemu tożsamości. To by w ogóle tego pojęcia nie było. Erikson o tym pisał, ale wtedy jeszcze mało kto, w ogóle pisał o tożsamości. To pojęcie nie było popularne. Nie sądzę, żeby ówczesny profesor dał Panu to za temat do pracy doktorskiej, bo to było tak oczywiste.

Dawniej problem polegał tylko na tym, co najwyżej, żeby się nauczyć reguł. Najwyżej przyswoić je sobie i praktykować. Nie mogę wypaść z koleiny. Nie mogę się wychylić. Nie mogę być inny. W jakimś sensie przytulnie było w tamtym świecie. Stara wspólnota, w której się człowiek rodził, w której miał pozostać, pilnowała, żeby się nie odchylać i w związku z tym było przykro, bo ciasno w świecie, ale zarazem człowiek czuł się bezpiecznie, bo nie było niespodzianek. On wiedział dokładnie, co trzeba robić. Tak. Dokładnie. Dzisiaj jest inaczej, dlatego, że z jednej strony jest kult autentyzmu, który gdzieś tam siedzi, w śledzionie...

R.H.M.: W nas.

Z.B.: Ja nie wiem, gdzie tam siedzi. W śledzionie.

R.H.M.: W nas?

Z.B.: W nerkach, czy w wątrobie, no, bo serce i mózg są zajęte innymi sprawami, ale gdzieś tam jeszcze musi być organ dla tożsamości, wewnętrzny. A z drugiej strony to żyjemy w świecie, który nazywam płynnie nowoczesnym i rzeczywiście panta rei, jakby rzekł Heraklit. I w związku z tym to, co było w lekcjach wczoraj, może być przepisem na katastrofę dzisiaj. Nie można założyć, jak Sartre chciał, że się w wieku adolescencji przyjmuje model, który się będzie stosowało do końca życia.

Dlaczego to jest problem? Dlatego, że ludzie borykają się z płynnością. Dlatego uważają tożsamość za przedmiot do kontynuowania. Tożsamość, ciągle pozostaje nierozwiązana, jest przedmiotem niekończącej się debaty. Co by się nie powiedziało w tej debacie, to zawsze znajdzie się ktoś, kto powie co innego. A sprawa jest essentially contested - jakby to powiedział Anglik. I to także sprawia, ta dwoistość sprawia, jak we wszystkich tego typu wypadkach, gdy człowiek ma kłopoty, kiedy dużo ludzi ma te kłopoty, to spieszy z pomocą rynek konsumpcyjny. Jest to wystawa etykietek, tych zewnętrznych wyrazów, jeżeli nie wewnętrznych przeżyć przynależenia, np. w kwestii tego, jaki mam style-hair, i do jakiej grupy w związku z tym należę. Rynek chytry, którego potrzebujemy, z jednej strony dostarcza materiałów do realizowania tego, co się nazywa wieczną teraźniejszością. $Z$ drugiej strony, każdy moment, jaki przeżywamy jest teraźniejszością. Każdy kolejny moment zawsze jest teraźniejszością, więc żeby być, zadomowić się w teraźniejszości, no to temu służy moda przecież. Tak? Bo w tamtym roku takie sweaters się nosiło, w tym roku inne. W zeszłym roku, wtedy takie ciężkie urządzenia się nosiło, dziś takie malutkie, przyjemne. Prawda? Że idziesz i w kieszonkę od kamizelki można schować, a z drugiej strony właśnie jest ten rynek, który daje możliwość szybkiego przeskoku. Bierze się tę maszynkę i wrzuca do śmieci i kupuje się nową. Tak zaktualizował się, zaabdejcił tak, jak to mówię, że zlongdejcił swoją tożsamość. 
R.H.M.: Analizując dyskurs dotyczący tożsamości, odnoszę wrażenie, że ktokolwiek podejmuje refleksje nad tym zagadnieniem, bardzo broni się przed ostatecznym zdefiniowaniem tożsamości.

Z.B.: Mówi Pan o mądrych ludziach.

R.H.M.: Dajmy na to, profesor Jolanta Miluska stwierdza coś takiego: ważne jest, aby odnajdujac nowe funkcje tożsamości wskazywać na nowe sposoby przejawiania się jej w świecie. Stąd moje pytanie. Jakie są funkcje tożsamości?

Z.B.: To nie jest z mojego słownictwa. Ja wyrabiałem sobie swój światopogląd socjologiczny w zmaganiu się z dominującą wówczas szkołą strukturalnego funkcjonalizmu Talcotta Parsonsa, dlatego nie lubię tego słowa „funkcja”. Sądzę, że ono nam podpowiada, że każde dziedzictwo społeczne, każdy element społeczeństwa, każdy kształt procesu społecznego i tak dalej, o tyle istnieje, że ma funkcje. Funkcje, wobec czego? Funkcje, jakie? Talcott Parsons mówi to samo - równoważący się system, a funkcja polega na tym, żeby służyć temu systemowi. „System” też nie jest z mojego słownika. Ja w ogóle tego nie pojmuję. Ja w ogóle uważam, że cechą tego, co Niemiec nazywa überlebten Welt, czyli świata przeżywanego jest jego niesystemowość, jego chaotyczność, jego różnorodność, jego wielorakość. I ta wielorakość jest w dodatku ruchoma, nie raz na zawsze ustalona, którą można inwentaryzować i składać. Jest taka, którą trzeba, jak to profesor Miluska powiedziała, zgłaszać o myślenie, którą trzeba ciągle dopatrywać, bo ona się zmienia. Tak?

R.H.M.: Gdybyśmy mogli odwołać się do sposobów przejawiania się tożsamości w świecie. We współczesnym świecie - dodam, to na co należałoby zwrócić uwagę?

Z.B.: W mojej socjologii: indywiduum jest tym. Taką podstawową syntezą klucza, o ile ujmuje się problem tożsamości. Taką książeczkę napisałem: Rozmowy z Benedetto Vecchim - nie wiem, czy Panu wpadła w rękę?

R.H.M.: Tak, mam. Niedawno przeczytałem.

Z.B.: Ja nie wiem, czy tam chociażby raz używam słowa funkcja. Nie pamiętam już. Nie sądzę, bo na ogół unikam tego słowa. Tożsamość jest sposobem bycia. Elementem sposobu bycia w świecie. A tym, co sprawia, że ona jest tym elementem sposobu bycia, jest potrzeba określenia, zrozumienia swojego miejsca w tym świecie. Problem tożsamości od dawna funkcjonował. Problem tożsamości ma bardzo poważną funkcję, skoro już mowa o funkcji, w stosunku do konsumpcyjnego rynku, o którym wspomniałem. Podając przy tym, że jest to produkt. Gdyby nie poczucie tożsamości, byłoby załamanie ekonomiki. Rynek obsługuje ten właśnie produkt, pomaga ludziom znajdować swoje miejsce w świecie. To można nazwać shoppingiem, eksplorowaniem tego, co shopping w Polsce, w świecie znaczy, co wystawia się na lady.

R.H.M.: Czyniąc to chociażby przez tak zwaną makdonaldyzację życia społecznego.

Z.B.: Między innymi. Także. I to tylko, że właśnie te funkcje są wtórne. One nie są siłą napędową problemu tożsamości. One są przejawem pasożytowania na istniejącym już problemie tożsamości. Bardzo wielu ludzi chce się pożywić tym, że ludzie przejmują się tożsamością. Dla mnie specjalnie o wiele ciekawsze jest to, że oni chcą się pożywić. To nic dziwnego. Nie odkrywamy ponownie Ameryki. Natomiast, dlaczego ludzie są tak tym przejęci? To już jest problem, a socjologia powinna służyć nie tyle uczonym recenzentom prac doktorskich, ile powinna służyć każdemu z nas. To znaczy moim zdaniem.

R.H.M.: Zwraca Profesor uwagę na indywiduum. Myślę, czy to oznacza myślenie o istocie człowieczeństwa, którą najpełniej wyraża nasza tożsamość?

Z.B.: O istocie człowieczeństwa? 
R.H.M.: Tak, o istocie człowieczeństwa. Czyli zakładam, że istotą człowieczeństwa jest nasza tożsamość. Czy też tożsamość - to istota naszego człowieczeństwa?

Z.B.: Tak, i jedno, i drugie. Ja nie widzę tu sprzeczności między jednym a drugim. Pan mówi o człowieczeństwie, ja mówię tylko i wyłączenie o ludzkim sposobie bycia w świecie. Chcąc wyrazić w sposób nieco uproszczony, o co nam w tym wypadku idzie, sięgam zwykle do argumentu języka. Jesteśmy jedynym gatunkiem zwierzęcym, my ludzie, generalnie biorąc, który ma język zawierający partykułę nie i zawierający czas przyszły. To dwie rzeczy niewyobrażalne w nieludzkim środowisku. Nie oznacza, że mogę zanegować, co doznaję. Mogę założyć, że jest coś takiego, co być nie powinno. Tak? A czas przyszły to znaczy, że mogę puścić wodze fantazji i wyobrazić sobie światy nieistniejące. Mogę sobie wyobrazić diabła-jednorożca, ale mogę sobie także wyobrazić inny gatunek społeczeństwa, w którym to, co jest słuszne - jest tu. Tam nie ma. Otóż te dwie rzeczy, te dwa nabytki związane z językiem: partykuła nie i czas przyszły, sprawiają, że człowiek nigdy nie jest dokończony. Nie jest do końca zdeterminowany. Nawet w Auschwitz czy w Treblince, które były jakimiś krańcowymi zupełnie przypadkami pozbawienia człowieka wolności, chociaż się tam pozostawało, można było rzucić się na naelektryfikowane druty i wybyć z gry. Ma się taką możliwość. Czyli my jesteśmy niepozbawialnie wolni i w związku z tym nieuleczalnie, nie do końca zdeterminowani. Gdyby nie to, nie troszczylibyśmy się o swoją tożsamość. Prawda? Tymczasem musimy się doterminować. Natomiast świat się rusza, a nie siedzi na tyłku, więc musimy tę czynność w zasadzie uprawiać w nieskończoność.

R.H.M.: Na dzień dzisiejszy, nie sposób wyobrazić sobie by powstała akceptowalna powszechnie definicja tożsamości. Czy taka ewentualność może zaistnieć w przyszłości?

Z.B.: Nie. Mogłaby tylko na siłach związanych z totalitaryzmem. Zresztą przed chwilą powiedziałem, że w totalitaryzmie, też nie można było tego ideału porządnie raz na zawsze sformułowanej tożsamości zrealizować. Dlatego na przeszkodzie stoi to, co Pan nazywa istotą człowieczeństwa, a ja nazywam sposobem ludzkiego bycia w świecie, ale to na jedno wychodzi. Tak? Zauważono, że wszelkie takie próby do końca się nie powiodą. W moim przekonaniu, dzisiaj szczególnie to jest wszystko drastyczne. Upłynnienie nowoczesności jakoś uwypukliło, odsłoniło te podwodne rafy, podwodne skały, problemy, które jak żeśmy kiedyś nie żeglowali, to wspólnie mogliśmy się przed mini uchronić. Tak, więc to, o czym mówię, szczególnie dobitnie unaoczniło ten problem niedookreślonej tożsamości. Jednak ta zmiana społeczna, która w tej chwili następuje w świecie, tylko uwidoczniła to, co w głębi zawsze tkwiło i zawsze tkwić będzie. To potrzeba bycia ludźmi. Pan proponuje w gruncie rzeczy skamienienie tego, co jest płynne. Tak? I co się stanie, to stać się może przecież. Kto wie? Étienne de La Boétie - jak Panu wiadomo, pisał o zjawisku, przypisywał człowiekowi w ogóle cechy niewolnictwa $\mathrm{z}$ wyboru: voluntary servitude. Ludzie się lepiej czują, jak zrzucają z barków odpowiedzialność za swoje własne czyny. Ktoś im jakoś mówi, każe, dokładnie, co mają mówić, czynić: „Ja ponoszę odpowiedzialność, ufajcie mi, bądźcie cierpliwi możecie spać spokojnie”. I Étienne de La Boétie powiedział, że to jest ludzka skłonność. Tak naprawdę, na dobrą sprawę wolą to, od konieczności szarpania się i posiadania nieczystego sumienia oraz pakowania się czasami w nieuchronne błędy i niepewność. Ale moim zdaniem Étienne de La Boétie chwycił tylko jedną stronę człowieka, bo z drugiej strony to właściwie jest dokładnie odwrotnie. Mamy, każdy inne, sumienie. Na ogół inne. Na ogół przytłumione, ale każdy każe temu duchowi wyjść poza to, co jest, każe eksplorować nowe niepoznane jeszcze tereny. I jedna tendencja, i druga tendencja. Kondensuję tę dwoistość do problemu odwiecznej i nierozwiązywalnej sprzeczności w sposobie ludzkiego bycia w świecie. To mianowicie mam na myśli. Konflikt, a zarazem nierozłączność dwóch wartości w ludzkim życiu. Jedna to wartość bezpieczeństwa, a druga to wartość wolności. Bez siebie one istnieć nie mogą. Bez siebie to one nie są wartościami, a koszmarami. Wolność bez bezpieczeństwa to chaos, zamęt, bezsens i absurd. Znowu bezpieczeństwo bez wolności to niewola. Jedno i drugie bez siebie to nie wartości. Tylko 
przeciwnie, antywartości, więc trzeba mieć obie wartości razem. Bezpieczeństwo i wartość wolności. Szkopuł polega na tym, że chociaż dwie, to trudno je ze sobą pogodzić. Zawsze, jak Pan chce więcej bezpieczeństwa, to musi Pan złożyć w ofierze cząstkę swojej wolności. Jak Pan pragnie więcej wolności, to musi Pan się zgodzić na to, że będzie się czuł Pan mniej bezpieczny, bo tam jest ryzyko, tam trudne decyzje. Niewiadomo, czy dobre, czy złe i zawsze jakaś ignorancja, co do tego, w jakich warunkach Pan te decyzje podejmuje. I zawsze jest tu obecny jakiś element impotencji, że Pan chce czegoś, ale nie bardzo potrafi. Jednym słowem z tego bałaganu się nie wydobędziemy, chyba że jesteśmy jak Baron Münchhausen, że się za własną perukę będziemy wyciągali z bagna. Ale przecież Münchhausen dlatego był wielki, że był jedyny w swoim rodzaju.

R.H.M.: W tej sytuacji, sądzę, że należałoby się odwołać do Kanta i jego imperatywu kategorycznego: Postępuj tylko wedle takiej maksymy, co do której możesz zarazem chcieć, aby stała się prawem powszechnym.

Z.B.: Tak, tak. No oczywiście, że jedyne nogi, na których to stoi, to jest po prostu zgoda dużej ilości ludzi, że tak właśnie jest, a nie inaczej. No tak, tylko, że Kant jeszcze dociekał praw sub specie aeternitatis - szukał praw ostatecznych, ważnych dla wszystkich. On nie zdawał sobie wtedy jeszcze sprawy, mimo że napisał esej, co to jest oświecenie. Prawda? Po raz pierwszy filozof, który napisał o zdarzeniu historycznym. Oświecenie było wydarzeniem historycznym. Nie pisał o wieczności, tylko o zdarzeniu historycznym. Mimo że nie zdawał sobie sprawy, do jakiego stopnia to poczucie historyczności, tymczasowości, przejściowości każdej sytuacji, opanuje ludzkość, tak jak dzisiaj. Wszystko jest dozwolone. Każda prawda, każda słuszność ma wymiary temporalne.

R.H.M.: Czyli powinniśmy zatem powiedzieć, że to jednostka bardziej stwarza i kreuje społeczeństwo? Czy też odwrotnie, społeczeństwo bardziej stwarza i kreuje jednostkę?

Z.B.: Ja zauważyłem, że ma Pan skłonności do formułowania dylematów, a to nie jest zgodne z tym, jak świat wygląda. Otóż w świecie są nie tyle dylematy, ile dialektyczne powikłania. Prawda? To znaczy sprzeczność, ale sprzeczność, która nie może istnieć w płynnej nowoczesności samodzielnie. To nie jest tak: sprzeczność, w której: albo - albo. To jest taka sprzeczność, w której i - i, a nie albo - albo. Tylko: i - i. Kto powiedział o formowaniu człowieka przez społeczeństwo albo społeczeństwa przez człowieka? I obie rzeczy są prawdziwe naraz, to nie jest albo - albo. My kształtowani jesteśmy przez społeczeństwo, które kształtujemy.

R.H.M.: Kształtowani jesteśmy przez społeczeństwo, które kształtujemy?

Z.B.: No, tak jest. Nie można wyobrazić sobie człowieka bez społeczeństwa i społeczeństwa bez człowieka. Oni są skazani na współżycie i wszystko polega na modus vivendi, na sposobie współistnienia tych dwóch elementów.

R.H.M.: Czyli na zasadzie splątanego consensusu?

Z.B.: Tak. Im bardziej my jesteśmy kształtowani przez społeczeństwo, tym bardziej my je w jakimś sensie w końcu kształtujemy. Przez to na przykład, że skłaniamy to społeczeństwo do samoodtwarzania się w tej samej formie. Albo, że ukształtowani jesteśmy przez to społeczeństwo tak, żeby czuć się indywiduami niepowtarzalnymi. Żeby być opanowani pragnieniem nowości, pragnieniem transgresji, pragnieniem postępu i w związku z tym rozkładamy tę systemowość społeczeństwa.

R.H.M.: Czyli omijać dylematy?

Z.B.: No chyba tak. Ja po prostu dawno temu przestałem myśleć o rzeczywistości społecznej w kategoriach dylematu i antynomii. Skazani jesteśmy na współżycie w warunkach nieustającej ambiwalencji i - i, teraz, nie: albo - albo. Tak, tak mi się wydaje. 
Jeżeli Pan pyta o moje zdanie i ma się pisać swój subiektywny pogląd, to ja Panu coś powiem. To jest problem. Problem, do którego doszedłem po sześćdziesięciu paru latach zajmowania się socjologią. Tożsamość - od tego zacząłem naszą rozmowę, to zarazem jest problem bycia sobą oraz problem zachowania możliwości stania się kimś innym. Bez współgrania tych dwóch, jak Pan to mówi antynomicznych, czy przepraszam, dylematowych rozwiązań, bez ich powiązania bez ich współżycia, współistnienia, trudno sobie wyobrazić w ogóle zagadnienie tożsamości. Nie byłoby tego zagadnienia. Nie byłoby pańskiego doktoratu.

R.H.M.: Dziękuję za cenne wskazówki.

Z.B.: No tak, powiedziałem, jak myślę na ten temat. Dobry przykład weźmy z małżeństw. Pan nie ma osobistego doświadczenia jeszcze w małżeństwie. A w małżeństwie tak jest. Małżonkowie się kłócą. Nie słyszałem jeszcze o małżeństwie, w którym nie byłoby kłótni. Jeżeli małżonkowie mówią, że się nigdy nie kłócą to widocznie jedno drugiemu jest obojętne. Są obojętni sobie nawzajem. Nie ma tam miłości. Jeżeli istnieje miłość, to trzeba się kłócić. W małżeństwie: Ja kocham Pana i chcę dla Pana najlepszego i z związku z tym mam taki ideał innej sytuacji dla Pana, który się zetknie z Pańskim wyobrażeniem o własnej tożsamości. Kłótnie są nieuniknione w małżeństwie, a zarazem, małżonkowie zdają sobie sprawę - dobrzy małżonkowie, kochający - że bez siebie im będzie jeszcze gorzej niż ze sobą, choć bycie ze sobą nawzajem oznacza codzienne kłótnie.

R.H.M.: Zatem jest wskazane, żebyśmy układali sobie życie z drugim człowiekiem. Niestety, można odnieść wrażenie, że dzisiaj ludzie, nie tylko młodzi, jednak zwłaszcza młodzi, czują się samotni, czy też są osamotnieni. Czy to wynika ze specyfiki naszych czasów? Z tego, co nam XXI wiek oferuje? Czy z jakichś innych przyczyn?

Z.B.: Nie. To wynika z dzisiejszej luźności stosunków wiążących ludzi, które są do odwołania. Dlatego wisi nad nami strach. Zmora. Zmora tego, że nagle znajdziemy się osamotnieni. Anthony Giddens, zna Pan takiego socjologa?

R.H.M.: Tak, znam.

Z.B.: On stworzył to pojęcie czystego stosunku, który uznaje za oznakę postępu moralnego i postępu w historii ludzkości. Co to jest czysty stosunek? To stosunek, do którego żadne nitki poboczne nie są uwiązane. Żadne zobowiązania długofalowe. Żadne jakieś postronne konieczności. Czysty stosunek opiera się tylko na jednej sprawie. Że bycie Pana i moje razem sprawia i Panu i mnie satysfakcję. Jak satysfakcja znika, powiada Giddens, to w czystym stosunku nie ma żadnych powodów, żeby kontynuować ten już niezadowalający, niesatysfakcjonujący stan. I tu jest ten szkopuł. Do zawiązania czystego stosunku trzeba dwóch. Obie strony muszą spodziewać się satysfakcji po tym stosunku, ale do jego zerwania wystarczy jednej. Jedna strona decyduje, że mam tego dość:. „Dosyć. To już mnie nudzi. To mnie nie zaspakaja, a w ogóle w sąsiednim ogrodzie kwiatki lepiej pachną". Prawda? I właśnie tak jest. Ponieważ do zawiązania stosunku trzeba dwóch, a do zerwania wystarczy jeden, więc obaj partnerzy żyją w strachu. Co będzie, jeżeli ten drugi, a nie pierwszy zdecyduje, że dość? I właśnie strach przed samotnością bardzo głęboko zakorzeniony jest w dzisiejszym pokoleniu. Kiedy walkmany, pierwszy przenośnik muzyki wprowadzono na rynek, to wprowadzono go pod hasłem:. Nigdy więcej samotności. Przemysł konsumpcyjny bardzo tego nadużywa. I bardzo wielu ludzi bało się, że wyjdzie na ulicę, a ona ucieknie. Tak, nigdy nie będziesz samotny, bo zawsze masz walkmana w kieszeni i możesz sobie posłuchać tych najświeższych czatów.

R.H.M.: Dzisiaj walkmana zastąpił telefon komórkowy.

Z.B.: Nie tylko, ale i facebook. Możemy mieć 500 przyjaciół na facebooku. To w ogóle nie ma problemu.

R.H.M.: Odnoszę wrażenie, że gdy ktoś ma 500 przyjaciół na facebooku, albo i więcej, to nie są to żadni przyjaciele. Tylko osoby. 
Z.B.: No tak, ale jak Pan spędza z nimi połowę czasu dnia, to już nie ma czasu martwić się, że brak przyjaciół. Cały czas wysyła tweetery do nich. Prawda?, Messangery, sms-y i otrzymuje i odpowiada. Full time job.

R.H.M.: Powinniśmy powiedzieć prawie dwudziestoczterogodzinny etat.

Z.B.: Tak. Już nie ma czasu na martwienie się. Ja nie mówię, że są to super przyjaźnie. Nie mam co do tego wątpliwości. Idzie o to, że nie ma okazji, żeby się tym martwić. Bo człowiek jest zajęty. Ma cały czas wrażenie bycia w towarzystwie. Jeżeli całe życie wypełnione jest tym wrażeniem, no to o to chodzi, to wszystko w porządku.

R.H.M.: Czyli zabieganie, że aż prawie zagubienie.

Z.B.: Właśnie - o! Bardzo ładne wyrażenie.

R.H.M.: Na myśl przychodzi mi ostatnia refleksja - spostrzeżenie. Ktoś kiedyś wspomniał, tylko teraz nie pamiętam, kto dokładnie, że nie należy poświęcać czasu komuś, kto nie ma go wystarczająco dla mnie.

Z.B.: To jest część tego całego systemu, o którym Pan wspomniał. Część całego systemu myślenia, który wynika stąd, że filozofowie od niepamiętnych czasów trudnili się rozumowym wyjaśnieniem korzyści z moralności. Moralności w sensie troszczenia się o drugą osobę. Nie udało im się to, ale poczynając od Arystotelesa, cały czas kierunek rozmyślań był taki, że moralność jest korzystna o tyle, o ile ma zawartą w sobie tendencję do wzajemności. Ja się o Ciebie troszczę i będę mógł się spodziewać Twojej troski w razie potrzeby. Prawda? Prawdziwego przyjaciela poznaje się w biedzie. To tego typu rozumowanie. Ludzie są dobrzy dla dobrych ludzi.

Jednak dobrzy ludzie w praktyce wiedzą dobrze, że są frajerami, po których inni jeżdżą. Zawsze znajdzie się mnóstwo takich, którzy będą to wyzyskiwali. Na tym polega cały problem, że moralność nie jest relacją wzajemności. A wzajemność gwałcona jest w dwóch kierunkach. Z jednej strony czynią to utylitaryści, którzy właśnie głoszą koncepcję: ,Jak Kuba Bogu, tak Bóg Kubie". Mówią oni o tym, jak odpłaci się po stokroć Twoja dobroć, bo będziesz ceniony przez ludzi, bo będą Twoimi przyjaciółmi. Z drugiej strony, Emmanuel Lévinas, który powiada za Dostojewskim, że moja odpowiedzialność za ciebie jest zawsze o krok, przed twoją odpowiedzialnością za mnie. Moja za ciebie jest zawsze większa. Na tym polega moralność. Nie czekam na wzajemność. Nie czekam na zrewanżowanie się. Nie czekam na odpłatę. Nie kalkuluję. W ogóle nie kalkuluję, po prostu troszczę się o drugiego człowieka. Tylko dlatego, że tak jak Luter, muszę powiedzieć: Ich kann nicht anders, nie umiem inaczej. Nie potrafię inaczej. Taka jest jakaś moja wewnętrzność.

R.H.M.: W takim razie ostatnie pytanie, które przychodzi mi ma myśl. Czy mógłby Pan Profesor, w zaledwie kilku zdaniach, patrząc z perspektywy swojego doświadczenia życiowego, relacji z drugim człowiekiem, określić, albo spróbować określić, jaki jest młody współczesny człowiek?

Z.B.: To, jak Pan powiedział, Pan już go określił: tak zabiegany, że aż zagubiony.

R.H.M.: Tak zabiegany, że, aż zagubiony.

Z.B.: Tak, dokładnie tak. I to nawzajem się podsyca, bo im więcej biega, tym bardziej zagubiony, im bardziej zagubiony, tym bardziej przyspiesza kroku. Samonapędzające się koło.

R.H.M. Dziękuję serdecznie za rozmowę.

Wywiad przeprowadził: 